\title{
LOS ESTILOS DE LO INDECIBLE: "AHI, PERO DOHDE, COMO"
}

\author{
MIGUELINA SOIFER
}

Cuando Cortazar escribe, como epígrafe a su cuen:o: "Un cuadro de René Magritte representa una pipa que ocupa el centro de la tela. Al pie de la pintura su título: 'Esto no es una pipa' (...)" no fue probablemente con la conciencia de estar caracterizando una de las técnicas del relato que inicia, o uno de los recursos expresivos de lo inefable: la mención por negación. Semejante a la tarea del místico, que debe dar cuenta de una experiencia sólo retable en la lengua alusivo-simbólica de la poesia, Cortázar crea sus procedimientos para expresar lo inexpresable, "eso que empieza en un sueño y vuelve en muchos sueños, pero no es eso, no es solamente un sueño", un estado ambiguo enire la vida y la muerte, que puede confundirse con el sueño, pero que no es e sueño: "Algo que pasa soñando, claro, puro sueño, pero después también ahi, de otra manera (...) (p. 93).

¿Qué constituye, en este texto, lo inefable? Ha muerto, hace treinta años, un íntimo amigo de juventud del narrador. Esta larga ausencia del amigo de infancia sigue irradiándole tonalidades enigméticas, determinando evocaciones indefinibles, vagos estados oníicos que pretende desvendar, buceando desesperadamente en su interior, creando sus particulares trampas lingüísticas para captar en los ecos vivenciales, esa realidad "intersticial" (el vocablo es cottazariano) que lo transciende.

Es un e:fuerzo proustiano de sondaje interior, operación lúcida que excluye toda liberación en el plano figurativo o simbólico: el cuento no recurre a mundos transfigurados ni metafóricos. Coloca a un lúcido narrador, verosímilmente coincidente con el autor - Cortázar - delante del viejo misterio: muerte, sueño, vida.

Muchas veces somos llevados a asociar al Sartre de La Nausée con Cortázar: la aproximación se da también en el texto ahora

I CORTAZAR, J. Ahi, pero dóndo, cómo. In. - Octagdro. Buenzs Aires, Sudamericano, 1974. 
analizado. Ahí pero dónde, cómo, es el relato de una experiencia, así como La Nausée es la "novela de una experiencia".

$\mathrm{Si}$ en Sartre las motivaciones filosóficas del novelista se refractan en un universo ficcional admirablemente tramado, donde destacábamos ${ }^{2}$ el proceso de metaforización de la realidad que daba génesis a la metáfora medular de la novela ("náusea") vemos instalarse en el cuento de Cortázar un único plano de narración en primera persona, casi unas páginas de diario cortazariano, donde la ecuación personaje $=$ narrador $=$ autor configura la unida estructura confesional.

Así este cuento, descarnado de toda bordadura simbólica en su esqueleto ficcional puede inte:pretarse como registro suscinto, una "mise au point" de la problemática del extrañamiento en Cortázar. Ahí pero dónde, cómo muestra la simple estructura de un texto que instaura el gran cuestionamiento existencial del hombre: los enigmas del ser, de la realidad y la existencia, paralelamente a las tentativas de solución o de respuesta a través del arte o la literatura.

Es por tanto el suyo (de Cortázar) como él mismo lo dice, un problema metafísico: el qué soy, el qué son la realidad y la existencia, y cuál el sentido último del mundo $y$ de todos nosotros. 3

Así, no sólo el aspecto instrumental estilistico confiere interés extraordinario al cucnto, sino tambiém la especulación cortazariana en torno a lo estético y a lo metafísico, la función asignada a lo literario-estético en sus implicaciones con la realidad y el misterio, filón temático infaltable en el bloque total de su obra, que en este cuento encuentra nuevas progresiones y vislumbres. Inclusive la prospección analítica sobre la función de lo literario que se transpone en el texto en estudio, se opera por la mencionada fusión narradorautor que es el soporte de la ficción.

Es Cortázar quien lleva a estas póginas su confesión, sus fantasmas y sus búsquedas, transformando el cuento en un documento precioso y a:larador del perfil humano del escritor: no es Paco el protagonicta, sino el narrador, verdadero agonista unamunesco. Las contadas referencias anecdóticas no destruyen, antes ffeverzan la imagen identificadora de narrador a autor: "ahora me iré a trabajar, me encontraré con traductores y revisores en la confe:ecna de Ginebra donde estoy por cuatro semanas (...)". (p. 95).

2 Da náusea so éxiuse: 'La Nausée' Humenilas (12) 106, 1969.

3 Flores, F.G. El lizismo metafísica de Julis Cortózar. Cuslernos Hispana imericano (289/290) 18 ago. 1974. 
Es la fascinante imagen del hombre perplejo ante lo insondable, lo que el relato nos descubre. La profunda ambiguedad del texto es la del excelente cuento, encerrando una más de las trágicas interrogaciones: al "ubi sunt?", al " $i$ qué se hicieron?" manriquiano se suma antológicamente este inmenso "¿pero dónde, cómo?". Bien dice Félix Gabriel Flores que:

en el itinerario que lleva cumplido el autor de Rayuela no sólo como escritor sino también como individuo, después de 1960, la dualidad creador-hombre se va resolviendo en una unidad cada vez más sólida y tal vez definitiva.

Así la pura opción del autor frente al binomio misterio - realidad/literatura es la determinante del eje generador de la expresión:

es él bruscamente: ahora (antes de empezar a escribir; la razón de que haya empezado a escribir) (...) (p. 92).

rezan las líneas iniciales del cuento. Roquentin - nuevamente la aproximación a la Nauséo - también emprende el relato de su náusea para "sacar a la luz" ciertas experiencias. Pero si el texto concretiza el acto creador, la escritura es el único instrumento posible en el acceso al misterio, búsqueda, para Cortázar, tal vez no destinada al fracaso:

que escribiéndolo por lo menos lucho con lo inapresable, paso los dedos de las palabras por los agujeros de esa trama delgadisima (...) (p. 95).

una zona otra (...) aunque la expresión sea incorrecta, pero también hay que superponer o violar las palabras si quiero acercarme, si espero alguna vez estar. (p. 98).

Lo literario es así un testimonio, que el ser asume, de reconocimiento del misterio, aunque no lo sea de su elucidación:

No voy a perder más tiempo; si escribo es porque sé, aunque no pueda explicarme qué es eso que sé, y apenas consiga separar lo más grueso, poner de un lado los sueños, y del otro a Paco, pero (...) (p. 97).

¿Hasta qué punto cree Cortázar en la eficacia de lo literario como vía de acceso a la realidad última? Un lento ritmo de elegía y desesperanza se difunde por el relato: flujo melancólico no centrado en torno a la muerte del amigo, sino resultante del desa'iento del autor, de su conciencia de estar trabando una lucha muy desigual contra lo "inapresable", ritmo de queja, en fin, del desalentado anhelo de trascendencia: 
Te digo, esos 31 años no son lo que importa; mucho peor es este paso del sueño a las palabras (...) (p. 95).

Desgarrado entre la confianza en la palabra y la conciencia de de que su lengua es "incapaz de vértigo", Cortázar pasará por todas las etapas de una lucha que impilica, inclusive, un trituramiento de la expresión: "hay que superponer o violar las palabras si quiero acercarme, si espero alguma vez estar". (p. 98).

Pero empecinadamente se formula la confianza en la palabra, pues es consubstancial al modo de ser del escritor: "Tratar de decirlo de otra manera; insistir: por esperanza, buscando el laboratorio de la medianoche, una alquimia impensable, una transmutación". (p. 102).

Implícitamente, es la esperanza en la creación literaria como proceso de transmutación de la intuición, laboratorio operando el acceso o la aproximación a lo invisible. La necesidad de registrar la experiencia ("simplemente tenía que decirlo"), de hacerla reconocible, no como individual y única, sino como uno de los posibles modos de interferencia de lo trascendente en el plano humano, confiere a la expresión el peso irrefutable del testimonio auténtico:

no habré podido hacerte vivir esto, lo escribo igual para vos qua me leés, porque es una manera de quebrar el cerco, de pedirte que busques en vos mismo si no tenés también uno de esos gatos, de esos muertos que quisiste y que están en ese ahí que ya me exaspera nombrar con palabras de papel". (p. 105).

$Y$ aun, en esta persecución metafísica, la literatura acoge una función plenamente "humanizada" - valga la inadecuación paradójica del adjetivo-: la de código de contacto con algún limbo donde el muerto fuese de alguna manera sensible a los esfuerzos del amigo: "Lo hago por Paco, por si esto o cualquiera otra cosa sirviera de algo, lo ayudara a curarse o a morirse, (...)". (p. 105).

Ciertos procedimientos en la expresión de lo inefable confieren, deciamos, gran interés estilístico al texto. ¿Cuáles son a!gunos de estos recursos cortazarianos?

1) Las oposiciones: procedimiento largamente estudiado a propósito de los poetas místicos como fo:ma de exprimir lo inefable, obtiene por la confrontación de contrarios, la desintegración de los moldes lógicos, caracterizando aquello que la antítesis $u$ oxymoron

4 lbid. 
designa, como inédito, sobrehumano $y$ de imposible encuadramiento en la racionalidad.

En el texto en cuestión observamos casos de:

a) oposiciones disyuntivas: "él está o no está" (p. 93) "él es como un puro presente que se manifiesta o no" (p. 93) "él (...) está ahi, dentro y fuera" (p. 101)

b) oposiciones negativas: "nada empieza ni termina" (p. 102); "no hay llegada ni partida" (p. 93)

c) correlación de oposiciones: "cuando te veo, estoy durmiendo y no sé pensar, y cuando pienso estoy despierto pero sólo puedo pensar", donde las oposiciones son:

te veo / pienso

estoy durmiendo / estoy despierto

no sé pensar / sólo puedo pensar

2) Reiteración o repetición. Procedimiento espontáneo, casi un reflejo o hábito mental, "muletilla" que Cortázar trae a flote en el autoanálisis de su búsqueda:

Repetir, reiterar, fórmulas de encantamiento verdad, a lo mejor vos que me leés también tratás a veces de fijar con alguna salmodia lo que se te va yendo, repetís estúpidamente um verso infantil, arañita visiła, arañita visiła, cerrando los ojos para centrar la escena capital del sueño deshilachado, renunciando arañita, encogiéndote de hombros visita, el diarero llama a la puerta, tu mujer te mira sonriendo $y$ te dice Pedrito, se te quedaron las telarañas en los ojos y tiene tanta razón pensás vos, arañita visita, claro que las telarañas. (p. 96).

En este párrafo el autor integra a la descripción del procedimien. to, el relieve de su función ("fórmulas de encantamiento", "fijar con alguna salmodia lo que se te va yendo") con su empleo en el texto: "arañita visita".

Otro ejemplo de reiteración es la fórmula-título, repetida a lo largo de todo el relato. Es, por tanto, téen ca de función distinta de la delimitada por A.S. Mendonça " en Por uma teoria do simbólico:

"A sistemática repetitiva converge para acentuar a perda de informação do discurso que habita o conjunto pleno". La conclusión es, en el caso citado resultante del análisis de la reiteración en el poema No meio do caminho tinha uma pedra. 
3) Recursos tipográficos. La anulación de los signos de punfuación $y$ de las mayúsculas para subrayar lo inconexo e instantáneo de la experiencia esencial del euento, aparece ya en la primera línea: "no depende de la voluntad" (tipo normal) "es él bruscamente: ahora (...)" (tipo menor).

Los párrafos en caracteres tipográficos menores son utilizados para las tentativas de reproduzir la impresión cnírica que es el eje temático del cuento (p. 93, 102); el recuerdo de Paco (páginas 94, $96,99,101,104,105)$; y para expresar cierta exasperación que lo ininteligible y lo incomunicable de la experiencia provocam en el narrador-autor (p. 101). El mismo recurso visual se utiliza para las "salidas" del narrador de su plano, por la reflexión sobre lo escrito:

releer esto es bajar la cabeza, putear de cara contra un nuevo cigarrillo, preguntarse por el sentido de estar tecleando en esta máquina, para quién, decime un poco, (...) (100).

La supresión de los signos de puntuación e interrogación es en parte determinante del proceso de sintesis en la expresión-llave del texto: "ahí pero dónde, cómo". Trátase, en el discurso cortazariano, de un único sintagma compuesto de:

a) el demonstrativo locativo ahi;

b) el interrogativo locativo dónde precedido de la partícula adversativa (pero), significando la perplejidad que la designación ahí suscitó;

c) la perplejidad total en la interrogación cómo.

,Este sintagma sintetizando la interrogación obsesiva, sin respuesta, que es el substrato estructural del cuento, compone un vocablo periodal "que llega a la substantivación: „ese ahí pero dónde”, „ese ahí pero cómo".

4)Imágenes de ausencia o vacío. La inefabilidad de la experiencia y la designación de la meta trascendente, se opera por imágenes que presentan elementos abstractos o concretos a los cuales se atribuyen cualidades de intangibilidad: "pruebas de aire", "montoncitos de ceniza", "seguridades de agujero"; u objetos tangibles solamente por contigüidad espacial: "territorio contiguo", "pieza de al lado",

5 Mendonça, S.A. Pcr uma teoria do simbólico. Petropolis, Vozes, 1974, p. 65. 1962 , พ. 1, p. 47.

6 Back, E. \& Mattos. G. Gramb́tica Censtrutural da Lingua Porfuguesa. Sāo Paulo, F.T.D. 
"tiempo de al lado".

Una actitud cortazariana ante lo trascendente es el intentar ecuacionar el equilibrio entre lo físico y lo metafísico. Esta tensión, en el texto en estudio, se reduce a um mínimo; uno de los recursos que el autor encuentra es la utilización de los modos populares de lenguaje - voseo, palabras vulgares, expresiones coloquiales (el español popular, hablado por el pueblo de Buenos Aires) - al lado de la descripción de gestos impregnados de la universal rutina humana, en una tentativa de igualar el misterio a lo concreto, insiriéndolo en la experiencia cotidiana:

algo que pasa soñando, claro, puro sueño, pero después también ahí, de otra manera porque blando y lleno de agujeros, pero ahí mientrar te cepillás los dientes, en el fondo de la taza del lavabo lo seguís viendo mientras escupís el dentifricio o metés la cara en el agua fría, y ya adelgazándose pero prendido todavía al piyama, a la raíz de la lengua mientras calentás el café, ahí pero dónde, cómo, pegado a la mañana con su silencio en el que ya entran los ruidos del dia, el noticioso radial que pusimos porque estamos despiertos y levantados y el mundo sigue andando. (p. 93-4).

Adueñarse de lo trascendente, domesticar el misterio igualándolo al nivel de lo inmediato vital ¿ no es acaso lograr "la palabra esencial en el tiempo" de que hablaba Antonio Machado al proponer su defición de lo poético?

En esta verdadera caza al misterio, la tentativa de conversión a lo cotidiano se aproxima a otra actitud asumida por Cortázar: la tendencia a anular lo sobrenatural. Es un deseo de ordenar conforme a la razón, dejar claro o agotar que ninguna predisposición a entrar en "territorios diferentes" le deforma la percepción del acontecimiento que analiza. Tal tendencia "racionalista" tiene el efecto de dar mayor nitidez a los contornos del misterio: no se trata, aquí de la alucinación de un sensitivo:

Ves, eso es lo que sé, no es mucho pero lo cambia todo. Me aburren las hipótesis tempoespaciales, las $n$ dimensiones, sin hablar de la jerga ocultista, la vida astral y Gustav Mayrink. No voy a salir a buscar porque me sé incapaz de ilusión, o quizá, en el mejor de los casos de la capacidad para entrar en territorios diferentes. Simplemente estoy aquil y dispuesto, Paco (...) (p. 99).

$Y$ si algo sé es que no hay nada de sobrenatural en eso; 
tango mi idea sobre los fantasmas, pero Paco no es un fantasma. (p. 98).

No sirvo para ir más lejos, intentar cualquiera de los caminos que otros siguem en busca de sus muertos, la fe - los hongos o las metafísicas. Sé que no estás muerto, que las mesas de tres patas sen inútiles; no iré a consultar videntes, porque también ellos tienen sus códigos, me minarian como a un demente. Sólo puedo creer en lo que sé, seguir por mi vereda como vos por la tuya (...) (p. 103).

Conversión a lo cotidiano, declarada ausencia de disponibilidad a lo sobrenatural, son procesos que podremos yuxtaponer al procedimiento sartreano que estudiamos rotulándolo "técnica de degradação": '

A recriaçāo da experiência no plano da ficção obedece a um processo de degradação: a náusea - um êxtase degradado. Tal técnica de degradação estudada em sua motivavação e observada em seus aspectos e funçães, revela-se totalmente coerente e alcança plena eficácia no universo ideológico-existencial do romance, fundamentalmente em relação ao comportamento do protagonista, que se define por uma essencial atitude anti-mística, anti-subjetiva.

Extremamente, esta actitud redundará en una "condenación de lo literario" - en sentido más amplio que el verlainiano, del término "literario":

A recusa e o desprezo do confessional e do lírico levam a uma condenação do literário: "Je n'ai pas besoin de faire des phrases. J'écris pour tirer au clair certaines circonstances. Se méfjer de la litterature".

Roquentin - portavoz de Sartre - y Cortázar se reencuentran en esta problematizazión de lo literario. De lo retórico, lo sublime, a lo popular, de lo espiritual a lo fisiológico, de lo subjetivo-'írico, lo sobrenatural a la lucidez analítica: estos binomios antitéticos serían zonas de gravitación subordinantes - en la cosmovisión como en el estilo - de los escritores contemporáneos confrontados al misterio. Mientras en Sartre el universo ficcional se construye en torno a un eje metafórico, el texto cortazariano propone un total ajuste a la realidad de lo narrado, un equilibrio deseado y conseguido entre lo invi-

7 Da Nóusea ao extase: La Nause., p. 105. 
sible y lo cotidiano.

De los cuatro movimentos identificables en el anhelo de trascendencia, la alabanza inexiste, como ocurría en el mundo augustiante de Sobre los ángeles; pero se insinúa el registro de una extraña alegria, que nace de la empecinada aceptación del misterio: "Paco está vivo".

y la alegría deslumbrada que me da saberte vivo es más fuerte que la palidez de tu cara y la fría debilidad de tu mano; porque en pleno sueño no me engaño como me engaña a veces ver a Alfredo o a Juan Carlos, la alegría no es esa horrible decepción al despertar y comprender que se ha soñado, $(\ldots)$; y la alegría dura y está aquí mientras escribo, (...) (p. 103).

La queja se aproxima al impetu imprecatorio que tiene plena expansión en El perseguidor, aunque aquí se formula sin destinatario: "Esta rebelión y este asco contra lo que te pasa" (p. 100), pero al igual que la alegría - a'abanza, surge de la aceptación efectiva del misterio, a saber: "la pungente sencación de que Paco está vivo".

La misma total subordinación al misterio se expresa en el dina. mismo interrogativo portador de la queja:

cómo puede ser, qué es eso que fue, que fuimos en un sueño pero es otra cosa, vuelve cada tanto y está ahí pero dónde, cómo está ahí y dónde es ahí? ¿Por qué otra vez Paco esta noche, ahora que lo escribo en esta misma pieza, al lado de esta misma cama donde las sábanas marcan el hueco de mi cuerpo? ¿A vos no te pasa como a mí con alguien que se murió hace treinta años, que enterramos un mediodia de sol en la Chacarita, llevando a hombros el cajón con los amigos de la barra, con los hermanos de Paco? (p. 94)

¿Por qué vivis si te has enfermado otra vez, si vas a morirte otra vez? $Y$ cuando te mueras, Paco, ¿qué va a pasar entre nosotros dos? ¿Voy a saber que te has muerto, voy a soñar, puesto que el sueño es la única zona donde puedo verte, que te enterramos de nuevo? $Y$ después de eso, ¿voy a dejar de soñar, te sabré de veras muerto? (p. 101).

La búsqueda se depara con un trascendente post-mortem, estado definitivamente impenetrable; sin embargo, el autor justifica el anhelo, la lucha "por lo menos con lo inapre:able", con el lenguaje por arma 
e instrumento; lucha que lo "acerca", le permite "esperar", "alguna vez estar", esperar "una transmutación"; $y$ al mismo tiempo quebrar "el cerco" de lo individual y único a través de la comunicación lingǘstica, y humana; tentativa que, de alguna manera, permita al narrador vencer el "infersticio" hacia el desaparecido, para ayudarlo "a curarse o a morirse".

La meta que excede al ser es, asi, un misterio indefinible que se desea desvendar: ni impresión onírica, ni sensación real: "algo que no es el sueño". La intuición del misterio se da en proceso semejante al del éxtasis: independiente de la voluntad, repentino e instantáneo:

no depende de la voluntad (p. 93)

es él bruscamente: ahora (...) (p. 93)

con actualización del absoluto temporal: "(...) puro presente que se manifiesta e no en este presente sucio, (...)" (p. 93)

Ahi pero dónde, cómo, está en el límite de la experiencia místico-poética: la confrontación al misterio es una desesperada actitud profundamente lúcida, que al aprehender sus propias limitaciones acaba minando la misma facu'tad figurativa. Pero no destruye la imantación del misterio, ese anhelo de trascendencia eje dorsal de la estructura estudiada. Al imperativo centrado en la fórmula cortazariana: "Fijarlos, y si es posible, serlos", se opone este "saber que no, que mi vida me encierra en lo que soy, al borde mismo pero" (p. 102).

Como si todo dependiera de mí, de una simple clave que un gesto $o$ un salto me darían y saber que no, que mi vida me encierra en lo que soy, al borde mismo pero ( $p$. 102)

y sin embargo, saber que "pero tiene que haber un porqué". (p. 100)

La lengua de Ahí pero dónde, como, construye un texto clásico, en el cual las tentativas de traducir lo inefable forjan una expresión plástica, multialusiva y sintética a un tiempo, cuya originalidad da la medida del insiztente anhelo que la inspira; creación lingüística mucho mayor que sus componentes de estilo, de máxima tensión creado. ra. "Com o horizonte da expressão humana por limite", consigue un máximo de fulguración expresiva, atacando esos límites "por acumulación y no por destrucción" ¿Como reconocer estiIhaçamento", "autodestruição", en la lengua capaz de forjar el siguiente texto, tomado como ejemplo al azar entre las páginas del relato?

no depende de la voluntad

es él bruscamente: ahora (antes de empezar a escribir; 
la razón de que haya empezado a escribir) o ayer, mañana, no hay ninguna indicación previa, él está e no está; ni siquiera puedo decir que viene, no hay llegada ni partida; él es como un puro presente que se manifiesta o no en este presente sucio, lleno de ecos de pasado y obligaciones de futuro

A vos que me leés, ¿no te habrá pasado eso que empieza en un sueño $y$ vuelve en muchos sueños pero no es eso, no es solamente um sueño, algo que está ahí pero dónde, cómo; algo que pasa soñando, claro, puro sueño pero después también ahí, de otra manera porque blando y lleno de agujeros pero ahí mientras te cepillás los dientes, en el fondo de la taza del lavabo lo seguís viendo mientras escupís el dentifricio o metés la cara en el agua fría, y ya adelgazándose pero prendido todavía al piyama, a la raíz de la lengua mientras calentás el café, ahí pero dónde, cómo, pegado a la mañana, (p. 93)

\section{Resumo do artigo}

\section{Miguelino Soifer}

Análise do conto Ahi, pero dónde, cómo, do livro "Octaedro", de Julio Cortázar, a partir da motivação místico-poética (procura de uma verdade transcendente), com ênfase no estudo da elaboração formal inerente, e nos recursos lingüísticos criados pelo autor para exprimir sua experiência indizivel.

8 Arriguci, D. O Escorpitio encalecrado. Säo Paulo, Perspectiva, 1973. 353 p. 